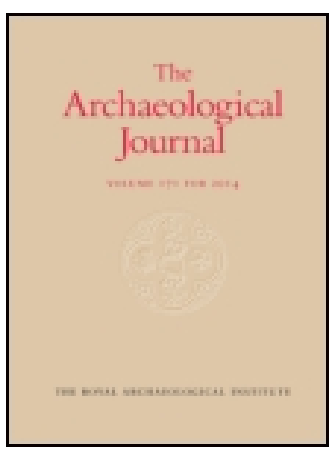

Archaeological Journal

\title{
Notices of Ancient Ornaments and Appliances of Sacred Use
}

A. W.

To cite this article: A. W. (1847) Notices of Ancient Ornaments and Appliances of Sacred Use, Archaeological Journal, 4:1, 239-248, DOI: 10.1080/00665983.1847.10850659

To link to this article: http://dx.doi.org/10.1080/00665983.1847.10850659

曲 Published online: 06 Dec 2014.

Submit your article to this journal $₫$

$Q^{1}$

View related articles $\asymp$ 
interesting documents have been supplied. I hope, by the same obliging permission, which has enabled me to bring them before the readers of the Journal, to draw from this source further illustrations of the manners and enterprise of the chivalrous times of Henry VI., especially as displayed in the feats of arms of Sir John de Astley.

ALBERT WAY.

\section{NOTICES OF ANCIENT ORNAMENTS AND APPLIANCES OF SACRED USE.}

THE SUPER-ALTAR, ALTARE VIATICUM, ITINERARIUM, PORTATILE, GeSTATORIUM, LEVATICUM, PARATUM, OR TABULA ITINERARIA.

From an ancient period it appears to have been customary in the Christian Church to appropriate, for the solemn service of the Eucharist, a tablet or portable substitute for the fixed altar, to be used as convenience might require. Some liturgical writers have considered that the origin of this practice may be traced only to the eighth century, but it is highly probable, as Dom Martene has remarked, that it existed even in the early ages of the Church. As soon as the primitive simplicity of Christian faith had given place to the feeling by which matters of external observance became regarded as of essential importance, perhaps even before temples were devoted to Christian worship, although it had become customary to set apart certain suitable vessels for the most solemn of Christian rites, the notion arose probably that the consecration of the elements upon tables of ordinary and profane use might be inconsistent with the reverence due to so sacred a service. Hence, doubtless, even in the early times of dispersion and persecution, and whenever access to a consecrated church was impracticable, the custom originated to which must be traced the use of the super-altare in the Latin, as also of the

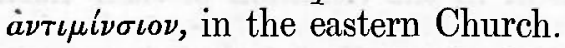

There can be no question that this attention to due solemnity in the celebration of this holy Sacrament was also observed, so far as circumstances permitted, by the zealous advocates of the faith through whose mission into heathen lands, the knowledge 
of Christianity reached the most remote parts of Europe. Thus, according to the relation of Bede, the two British missionaries, the white and the black Hewald, who took part with Wilbrord in his pious endeavour to introduce the faith into the barbarous regions of northern Europe, having been detected through their daily offering of the Eucharistic sacrifice, for which purpose they had provided themselves with sacred vessels and a tabula dedicated as a substitute for an altar, suffered cruel martyrdom amongst the ancient Saxons, in the seventh century .

Amongst the earliest evidences of the use of the super-altar in our own country the curious relations of the anonymous monastic chronicler, and of Reginald of Durham, respecting the translation of the remains of St. Cuthbert to the new church at Durham, in the year 1104, deserve especially to be noticed. They have given a detailed account of the state in which his remains were then found, with the vestments and sacred objects deposited with them at Lindisfarne, A.D. 688, including a small golden chalice, a paten, and a silver altar ${ }^{\mathrm{b}}$. The tomb in Durham cathedral supposed to contain the remains of St. Cuthbert, was opened in the year 1827; they were then found wrapped in rich pontifical vestments, and upon the breast of the corpse had been deposited a small portable altar of oak, covered with silver plate, curiously ornamented, and bearing an inscription. It is remarkable that on the wood itself was also found part of an inscription, concealed by the metal coating, as if it likewise had been used as a portable altar, previously to being thus decorated. Mr. Raine has given a detailed account and representation of this remarkable relic, now preserved in the Chapter Library, at Durham $^{c}$. It has been recorded that a similar portable altar, formed of two pieces of wood fastened together with silver nails, and inscribed, ALME TRINITATI AGIE SOPHIE SANCTE MARIE, was found in the tomb of Acca, bishop of Hexham, opened about the year 1000 ; Acca died A.D. $740^{d}$. There can be little doubt that the primitive bishops were accustomed to carry such altars with them in the visitation of their flock

a "Habentes secum vascula et tabulam altaris vice dedicatam."-Hist. Eccl. Ang., lib. v. c. 10 .

b "Habet secum in sepulcro altare argenteum et corporalia."-Regin. Monachi Dunelm. libellus, c. 42 . The anonymous history, printed in the Acta Sanctorum, iii. mens Martii, is closely in accordance with this account.

c Saint Cuthbert, by the Rev. James Raine, Durham, 1828, p. 199 , plate vi.

d Sim. Dun. Scriptores Decem, col. 101. 
dwelling in remote places, when few churches as yet existed in Britain, or in their journeyings to extend the knowledge of the faith, and thus provided, so far as it was then practicable, for the solemn performance of those rites by which they sought to impress the minds of their half barbarous converts with reverence.

Hincmar, archbishop of Rheims, in his Capitula, promulgated in 857 , distinctly enjoined that no priest should celebrate mass upon an altar which had not received episcopal consecration. He instructed his clergy, in case of necessity, until churches and altars should be dedicated, or in chapels which might not be thought to require consecration, to provide a tablet of marble, or of black stone, or "de litio honestissimo," (slate of the best quality?) according to their ability, upon which, after it had been brought to receive consecration by himself, the sacred mysteries might be celebrated consistently with the rites of the Churche. To the same effect are injunctions found in the Capitularia of Charlemagne, in regard to the mass, and the use of portable altars duly consecrated by a bishop, whenever in time of war, or during a journey, celebration in a church might not be practicable. An altar of this kind, supposed to have been used by Charlemagne himself during his wars, was preserved in the monastery of St. Emmeran, at Ratisbonf.

In subsequent ages the use of the portable altar appears to have become very prevalent, owing, probably, to the deficiency of churches, the increase of monastic establishments, the prescribed usage that required frequent celebration of mass by every priest, whilst it was never performed upon the same altar twice during the day, except on some extraordinary occasion. The crusades also, and other causes, of which the limits of the present notice will not permit a detailed investigation, occasioned the more frequent use of the tabula itineraria, and the restrictions by which the Church sought to limit the concession of such a privilege by bishops, frequently sought by those who desired, for mere personal convenience, the facility of celebration in their own dwellings.

Various usages and regulations were observed in the formation of the super-altar, at different times. In our own country, it would appear from the facts which have been stated, that in early ages it was formed of wood, cased and

e Bona, rerum liturg., lib. i. c. 20.

f Constit. Caroli Magni, ad finem. 
ornamented with metal; in later times it was customary that it should be of stone, for the sake of greater stability, as also in conformity with certain symbolical proprieties. The relics of martyrs were usually enclosed within it: the stone was properly to be of one undivided piece, firmly fixed upon a suitable stand or substratorium of wood or metal ${ }^{g}$. In the curious list of sacred ornaments presented to the church of Exeter by Bishop Leofric, who removed the see thither from Crediton, A.D. 1050, is mentioned an altar of bone, described in the Anglo-Saxon original as "gebonede altar," doubtless of the portable kind ${ }^{\mathrm{h}}$. The letters of Ivo, bishop of Chartres, towards the close of the eleventh century, as also those of St. Anselm, supply some curious evidence in regard to the super-altar. It was required that its dimensions should be sufficient to receive the chalice and the consecrated host'; in some instances it was of very moderate size, such as the altar of St. Cuthbert, which appears by the representation which Mr. Raine has given, to have measured about 6 in. by 5 in. An altar of small dimensions, preserved in the monastery of St. Laurence at Liege, is described by Dom Martene as formed of green stone, measuring 2 in. by 3 in., with an inscription upon brass recording its dedication, A.D. 1137, by Rodulf, bishop of Liege, and this distich :

Hic datur ipse Jesus animarum potus et esus, Hec tibi sit cara, cui caro fit, crucis arak

In later times it was ordained at the Council of Milan that the length of the portable altar should be at least $20 \mathrm{in}$. by 16 in. in width. Dom Martene has given several ancient forms or ordines for the consecration of the tabula or lapis itinerarius, shewing that relics were usually enclosed in a cavity termed sepulcrum, but according to the custom of some churches no relics were required. The benediction was accompanied by ceremonies similar to those customary in the consecration of fixed altars, and five crosses were traced either

g Charles the Bald presented to the church of St. Denis, according to the ancient inventories of that monastery, a portable altar of porphyry, of square form, enclosed in gold, standing upon four feet, and containing relics.- Irartene. It was very unusual to form such an altar with feet, as liable to render it insecure. There w:s, however, such an altar in the treasury of York Minster.-Mon. Angl., vol. iii. p. 174 .

h Mon. Angl., tom. i. p. 222. Orig. ed. i "Superaltaria nimis stricta non habeant, super que celebratur, sed competenter ampla." - Concil. Sarisb., A.D. 1217.

k De Antiqu. Rit., lib. ii. c. 17. 
with holy water or chrism upon the angles, or cornua, and in the middle of the stone'.

Many curious evidences exist in ancient inventories and documents illustrative of the prevalent use of the super-altar, its varied form and decoration. It was mostly of quadrangular shape, but in the list of benefactors to the abbey of St. Alban's, compiled towards the close of the fourteenth century, one of circular form is described, presented by a noble lady, and traditionally supposed to have been used by St. Augustine. "Domina Petronilla de Benstede dedit Sancto Albano unum super altare rotundum de lapide jaspidis subtus et in circuitu argento inclusum; super quod, ut fertur, sanctus Augustinus Anglorum Apostolus celebravit." Petronilla is represented in a marginal illumination, holding the object presented by her ; the round stone is coloured with vermilion, speckled with white; it is enclosed within a gilt margin, having on one side a ring, by which it might be held or suspended. According to the proportion of the drawing, this altar might measure about a foot in diameter ${ }^{\mathrm{m}}$.

A very remarkable super-altar was preserved at Glastonbury, until the Reformation, as appears by the list of jewels and precious objects, the plunder of the monasteries, delivered to Henry VIII., on May 15, 1539. It is described as "a superaltare garnished with silver and gilte, and parte golde, called the Greate Saphire of Glastonberye." The history of this curious relic has been preserved by William of Malmesbury, who designates it as the altar of Saint David, archbishop of Menevia, "quod dicitur vulgo, Saphirus." It was supposed to have been one of four gifts received by the saint from the patriarch of Jerusalem, whither David, in compliance with a miraculous warning, had journeyed, and received consecration as bishop from the patriarch's hands. On his departure he was presented with this " altare consecratum, in quo Dominicum corpus sacrabat," a bell, a pastoral staff, and a tunic ; the patriarch, observing that these objects might be burdensome during his journey, promised that he would convey them to St. David's dwelling; and according to the legend they were conveyed to him by angels. St. David presented the altar to Glastonbury".

1 De Antiqu. Rit., lib. ii. c. 17.

m Cott. MS. in Mus. Brit. Ntro, D. vii. f. 101, b.
" Gul, Malmesb. de Antiqu. Glaston. ed. Hearne, vol. i. p. 40. This altar, having been concealed during the wars, 
The early historians record the donation to various churches in England, of objects of a very precious description, described as altaria aurea, such as that which was bestowed upon the church of Glastonbury, by Ina, king of the West Saxons, estimated at 264 pounds of gold, and the altars with relics, given to Waltham Abbey by Harold, of which one was of gold; they were carried away to Normandy by the Conqueror ${ }^{\circ}$. Another costly altar of gold was presented to Glastonbury by Abbot Herlewin, at the commencement of the twelfth century; and William of Malmesbury describes the astonishment of a foreigner, who inspected it, (" altare, quod, cum Johanni Cremensi ostensum enormitate precii ejus hebetasset animum," \&c.,) affirming that, at Rome, it would be valued at a hundred marks of gold. These, and other like altaria, were probably altars of the portable kind.

The super-altars, described in the ancient inventories of churches in our country, were chiefly formed of precious stones, or costly marbles. In the treasury of York Minster, the following altars were found at the Dissolution. "Unum super altare pretiosum de jaspide, ornatum in circumferentiis cum argento et auro, ac lapidibus pretiosis, operis subtilis. Item, j. superaltare de rubeo jaspide, \&c. Item, ij. super altaria de rubeo marmore, ornato cum argento, quorum j. stat super iij. pedes argenti, et alterum sine pedibus, super quem S. Johannes celebravit, quando sibi apparuit Spiritus Sanctus, ut in sua legenda patetp." Herbert, archbishop of Canterbury, who died A.D. 1205, presented an " altare gestatorium de lapide calcedonio q." In the inventory of the treasury of St. Paul's, London, A.D. 1295, is found the item, "Superaltare de jaspide ornatum capsa argentea deaurata, et dedicata in honore beate Marie et omnium Virginum." At the altar before the cross, "in aquilonari," was found "unum superaltare de Loys," or slate, the same material which appears to have been designated by Archbishop Hincmar as litium; several like ornaments were found at other altars, and three in the church of St. Faith, in the crypts ${ }^{r}$. Occasionally, but contrary to customary usage, super-altars were formed of

was found and richly adorned by Abbot Henry about the year 1125 , in the times when that historian wrote.

- Gul. Malmesb. de Antiqu. Glaston. ed. Hearne. Harl. MS. 3776 .

p Mon. Angl., vol. iii. p. 174. Orig. ed.

q Gervasii actus Pontif. Decem Scrip- tores, col. 1684 .

r Dugdale, Hist, of St. Paul's Cathedral, pp. 204, 229, 232. ed. 1658. Amongst the relics is described a super-altar of jasper, enclosed in plates of silver gilt, in which were relics of St. Andrew, St. Philip, St. Denis, and St. Blase.-Ibid., p. 235. 
wood of some rare quality, instead of stone, such as the "ij. Tables de yban (ebony) pro superaltar's," valued at twenty shillings, in the Kalendars of the Exchequer, $12 \mathrm{Edw}$. III., A.D. 1338.

Many other notices might be brought together regarding super-altaria, used in England, such as occur in inventories of the treasuries of cathedral churches, of the collegiate chapel at Windsor, taken in $1384^{\mathrm{s}}$, and the lists of benefactions to various churches, frequently recorded by monastic chroniclers. The examples already cited may, however, suffice to shew of what materials these altars were formed, and the costly nature of their decoration. Several ancient altars of this kind still exist, well deserving of the attention of the antiquary, as remarkable examples of various artistic processes, or of symbolical design. Of one of these, now in our own country, I am enabled, by the kindness of the present possessor, the Rev. Dr. Rock, to offer representations in illustration of these notices. 'This highly curious super-altar, or " altarino vescovile portatile," as it is designated by the Count Cicognara, in whose collection it formerly was, is formed of oriental jasper, enclosed in silver, most beautifully ornamented with nielli, and ornaments engraved, pounced, or repoussés. At the four angles appear representations of the elements personified as females, crowned, and bearing appropriate symbols; on the upper margin is the Agnus Dei, the blood issuing from its breast, and received in a chalice; beneath is the holy dove, standing upon an altar. On either side of the lamb is introduced a figure of an angel, one holding the globe or mound, surmounted by a double cross, the other bearing a sceptre, symbols of sovereignty. The perfection and delicacy of workmanship, both in the nielli and the varied stippling of the field in the various compartments, some of which are finely cross-hatched, others being pounced with circles, or minute chevrons, as also the elegant foliated ornaments of the base, of which some notion may be obtained from the accompanying woodcuts, render this object one of the most curious existing specimens of the skill of the Italian orefici during the thirteenth century. Its dimensions are about 12 in. by $7 \frac{1}{4}$ in. It was formerly in the possession of the Cardinal Bessa-

8 Mon. Angl., tom. iij. Eccl. Colleg., p. 84. Several super-altars of jet (de Gete nigro-de geete) and of jasper were pre-

VOL. IV. served with the relics in the church of Durham, enumerated in the Appendix ta Bede, ed. Smith, p. 744. 
rione, who, shortly after the council of Florence, A.D. 1439, was appointed commendatario of the monastery of Avellana; he presented to the church of that abbey the remarkable altar now in Dr. Rock's possession, with other precious ornaments, described in the ancient records of Avellana. Count Cicognara has published a very elaborate fac-simile of the upper part of this super-altar, and of the nielli, in his Memoirs relative to the History of Chalcography ${ }^{t}$.

Several other ancient super-altars exist on the continent; one, bearing a very curious inscription, is preserved in the De Bruges collection at Paris. It is of the thirteenth century. Monsieur de Caumont describes another, in the church of Faye-l'Abbesse, Dep. des Deux-Sevres, traditionally supposed to have been used by St. ITilarius, in the visitations of his diocese. It is an oblong piece of marble, framed with metal, and has a handle affixed to the upper side ${ }^{u}$. Two ancient super-altars are preserved in the church of Conques (Aveyron). The more ancient is formed of agate, ornamented with enamelled plates; the other is of porphyry, bearing an inscription which records its dedication in the year 1106 . These have been minutely described by the Abbe Texier, in the Annales Archéologiques, published by Monsieur Didron $x$. Another, probably of the eleventh century, exists in the collection of M. Leven, at Cologne $e^{y}$. Its decorations are very curious, exhibiting personifications of the four rivers of Paradise, with figures of angels and seraphim.

The term super-altare, it must be observed, occasionally served to designate objects of sacred use, perfectly distinct from the portable altars above described. Thus, Matthew Paris, in the Lives of the Abbots of St. Alban's, describes the benefactions of Abbot John, who died A.D. 1214, amongst which were "tabula picta ante altare beate Virginis, cum superaltari cælato, et cruce superposita, et pictura desuper ;" and again, he mentions an altar made by Abbot William, the successor of John, in honour of St. Amphibalus and his companions, "cum tabula et superaltari pretiose pictisz." These were, possibly, the decorations placed above the altar,

\footnotetext{
t Memorie spettanti alla storia della Calcographia, del Comm. Conte Iseopoldo Cicogavara, Prato, 1831. t. i. p. 72. This beautiful altar was exhibited, by Dr. Rock's obliging permission, in the Museum formed during the meeting of the Institute at Winchester, 1845.
}

u De Caumont, Cours d'Antiquites Monumentales, vol. vi. p. 129.

$x$ Tome iv. p. 290.

y Heideloff, Ornementation au MoyenAge, livr. viii. pl. iii.

工 M. Paris, Vitæ Abb., p. 122. 

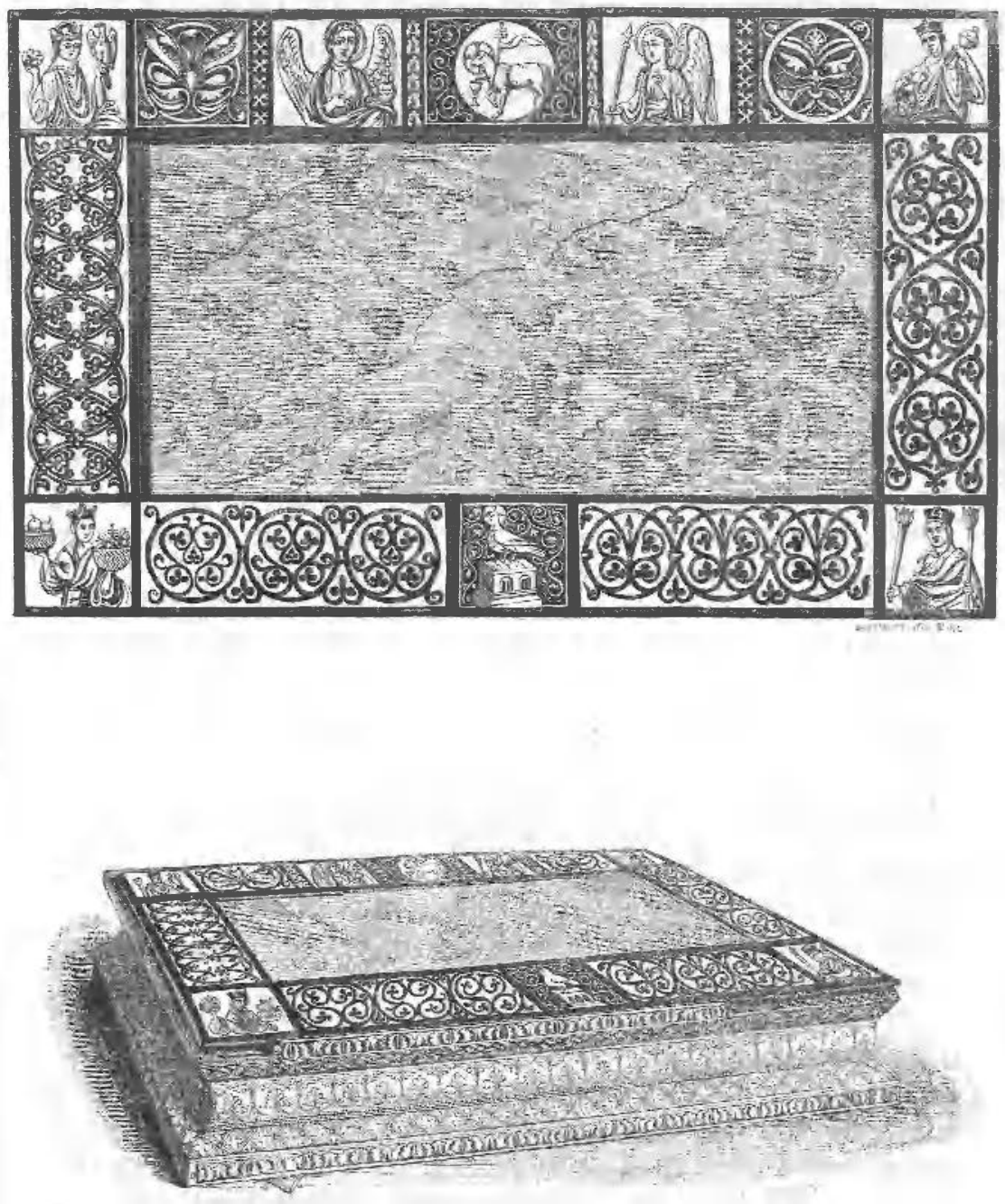

PORTABLE ALTAR OF ORIENILAL JASPRR: ORNAMENTED WITE NIELLO in the possession of the R.E. D. ROCK, D.D 
more properly termed retrotabula ; or, as Ducange supposes, the term may here denote the ciborium, usually placed above the altar, for the reception of the consecrated host therein to be reserved. Wats, however, in the glossary appended to his edition of the works of M. Paris, concludes that these ornaments were the portable altars of consecrated stone, marked with a cross, such as were used by the priests in the visitation of the sick, and commonly called, before the Reformation, " howselling altars." 'The description given by the historian seems scarcely to accord with this supposition.

The privilege of making use of portable altars appears to have been frequently a special concession from the Roman pontiff to individuals or communities. Blomefield has printed a grant from Pope Clement VI., A.D. 1353, to Sir John Bardolf, lord of Wermegay, and his wife, "ut liceat vobis habere altare portabile, cum reverencia et honore, super quod in locis ad hoc convenientibus et honestis possit quilibet vestri per proprium sacerdotem ydoneum missam et alia divina officia, sine juris alieni prejudicio, in vestra presencia facere celebraria." Weever cites a bull of Pope Martin V. (A.D. 1417-31) granting the like indulgence to the English merchants of the staple of Calais ; and one of the privileges conceded to the gild of our lady in St. Botolph's, at Boston, confirmed by Julius II., A.D. 1510, was the license " to carie about with them an aultar stone, whereby they might have a priest to saie them masse or other divine service, where they would, without prejudice of any other church or chapel, though it were also before day, yea and at iij. of the clock after midnight in the summer time. Item, that having their aultar stone, they might have masse said in any place, though it were unhallowed."

In the Greek Church the lapis sacratus, or portable altar of stone does not appear ever to have been used. Where a consecrated altar did not exist, it was customary to provide as a

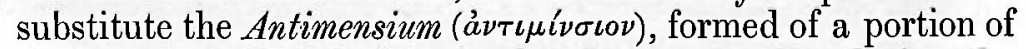
the covering which had been placed upon an altar during the ceremony of dedication. The customary Ordo for the consecration of antimensia is given by Goar, in whose Ritual and in the Glossaries of Du Cange full information may be obtained regarding this ancient usage of the Eastern Church ${ }^{b}$. A. w.

a Hist. of Norf., vol. iv. p. 210.

b Goar, Rituale Græcorum, p. 648.

Dom. Macer, in Hierolexico. Du Cange, in Glossariis Med. Latin. et infimæ Græcit. ad vocem. 